\title{
SOSIALISASI PEMULIHAN EKOSISTEM TERUMBU KARANG DI PERAIRAN DESA PENGUDANG KABUPATEN BINTAN
}

\section{Socialization of Coral Reef Ecosystem Recovery in the Waters of Pengudang Village Bintan Regency}

\author{
Dedy Kurniawan ${ }^{1 *}$, Aditya Hikmat Nugraha ${ }^{2}$, Wahyudin ${ }^{3}$, Jumsurizal $^{4}$, Try Febrianto ${ }^{2}$, \\ Susiana $^{1}$, T. Ersti Yulikasari ${ }^{5}$ \\ ${ }^{1)}$ Program Studi Manajemen Sumberdaya Perairan, Fakultas Ilmu Kelautan dan Perikanan, \\ Universitas Maritim Raja Ali Haji, Tanjungpinang \\ ${ }^{2)}$ Program Studi Ilmu Kelautan, Fakultas Ilmu Kelautan dan Perikanan, Universitas Maritim \\ Raja Ali Haji, Tanjungpinang \\ ${ }^{3)}$ Program Studi Sosial Ekonomi Perikanan, Fakultas Ilmu Kelautan dan Perikanan, \\ Universitas Maritim Raja Ali Haji, Tanjungpinang \\ ${ }^{4)}$ Program Studi Teknologi Hasil Perikanan, Fakultas Ilmu Kelautan dan Perikanan, \\ Universitas Maritim Raja Ali Haji, Tanjungpinang \\ ${ }^{5)}$ Jurusan Pemanfaatan Sumberdaya Perairan, Fakultas Perikanan dan Ilmu Kelautan, \\ Universitas Riau, Pekanbaru
}

*Korespondensi : dedykurniawan@umrah.ac.id

\begin{abstract}
ABSTRAK
Kegiatan pemulihan ekosistem terumbu karang di Kabupaten Bintan merupakan kegiatan pemulihan ekosistem terumbu karang berbasis masyarakat yang dilakukan dalam upaya perlindungan ekosistem terumbu karang, serta pemulihan kerusakan lingkungan pesisir dan laut melalui pemulihan kerusakan ekosistem terumbu karang berbasis masyarakat di Perairan Desa Pengudang, Kabupaten Bintan. Kegiatan sosialisasi pemulihan ekosistem terumbu karang di Perairan Desa Pengudang, Kabupaten Bintan melibatkan masyarakat Desa Pengudang, Pokdarwis Pengudang Bintan Mangrove, Yayasan Ecology, Dinas Lingkungan Hidup dan Kehutanan Prov. Kepulauan Riau, Dinas Lingkungan Hidup Bintan, Dinas Kelautan dan Perikanan Prov. Kepulauan Riau dan Dinas Perikanan Kabupaten Bintan.
\end{abstract}

Kata kunci : Sosialisasi, Transplantasi, Terumbu Karang, Kabupaten Bintan

\begin{abstract}
The restoration of coral reef ecosystems in Bintan Regency is a community-based restoration of coral reef ecosystems carried out in an effort to protect coral reef ecosystems, as well as restoration of damage to the coastal and marine environment through community-based restoration of damage to coral reef ecosystems in the waters of Pengudang Village, Bintan Regency. The socialization activity for the restoration of coral reef ecosystems in the waters of Pengudang Village, Bintan Regency involved the people of Pengudang Village, Pokdarwis Pengudang Bintan Mangrove, Ecology Foundation, Dinas Lingkungan Hidup dan Kehutanan Prov. Kepulauan Riau, Dinas Lingkungan Hidup Bintan, Dinas Kelautan dan Perikanan Prov. Kepulauan Riau dan Dinas Perikanan Kabupaten Bintan.
\end{abstract}

Keyword : Socialization, Transplantation, Coral Reef, Bintan Regency 


\section{PENDAHULUAN}

Indonesia dikenal sebagai negara megabiodiversitas yang memiliki kekayaan keanekaragaman hayati yang melimpah. Sebagai negara maritime, Indonesia mempunyai potensi di bidang kelautan yang cukup besar dan perlu dikembangkan dan dikelola dengan baik. Dalam hal ini, Indonesia mempunyai luas wilayah perairan sebesar $3.257 .483 \mathrm{~km}^{2}$ dengan panjang garis pantai $99.093 \mathrm{~km}^{2}$ serta jumlah pulau 13.466 pulau. Di sepanjang garis pantai dan sekeliling pulau-pulau yang ada terdapat ekosistem terumbu karang yang mempunyai banyak peranan namun rentan terhadap perubahan. Berdasarkan citra satelit, diperkirakan luasan terumbu karang di Indonesia adalah 2,5 juta hektar (Adrian et al., 2021). Menurut Hadi et al. (2018), kondisi terumbu karang di Indonesia dalam kategori kurang baik sebesar $36,18 \%$, cukup baik sebesar 34,3\%, baik sebesar $22,96 \%$, dan sangat baik sebesar $6,56 \%$.

Salah satu perairan Indonesia yang memiliki sumberdaya terumbu karang adalah Kabupaten Bintan. Kabupaten Bintan merupakan sebuah kepulauan di Propinsi Kepulauan Riau yang memiliki luas 1.318 $\mathrm{km}^{2}$ yang terletak di bagian selatan Laut Cina Selatan dan berbatasan dengan Kabupaten Batam dan Singapura (Kurniawan et al., 2019). Topografi daratan yang cukup landai, banyak muara sungai dan teluk, membuat kawasan pesisir Kabupaten Bintan memiliki ekosistem pantai pesisir yang lengkap. Perairan Kabupaten Bintan memiliki berbagai ekosistem laut dangkal yang merupakan tempat hidup dan memijah ikanikan laut seperti ekosistem mangrove, lamun dan terumbu karang (Suharsono et al., 2014). Hasil penelitian Rahmawati \& Hernawan (2019), menunjukkan kondisi tutupan karang hidup di Perairan Kabupaten Bintan termasuk dalam kategori cukup baik.

Seiring dengan berjalannya waktu dan pesatnya pembangunan di segala bidang serta krisis ekonomi yang berkelanjutan telah memberikan tekanan yang lebih besar terhadap lingkungan sekitarnya, khususnya lingkungan perairannya (Bukhari et al., 2021). Serta, menjadi salah satu ancaman bagi keberlangsungan ekosistem terumbu karang. Sehingga diperlukan upaya perlindungan dan pengelolaan ekosistem terumbu karang di setiap daerah menjadi lebih efektif dan efisien (Kurniawan et al., 2021).

Salah satu upaya perlindungan ekosistem terumbu karang dapat dilakukan melalui program pemulihan terumbu karang berbasis masyarakat. Keterlibatan masyarakat memperbesar keberhasilan proses pemulihan yang membutuhkan pengawasan selama berjalannya program (Lubis et al., 2016). Melalui transplantasi terumbu karang, ekosistem diperbaiki dengan meningkatkan luasan tutupan karang sehingga mempercepat proses restorasi kawasan yang mengalami kerusakan (Edwards \& Gomez, 2008). Teknologi transplanstasi karang (coral transplantation) adalah usaha mengembalikan terumbu karang melalui pencangkokan atau pemotongan karang hidup untuk ditanam di tempat lain atau di tempat yang karangnya telah mengalami kerusakan (Suharsono, 2008; Suharsono et al., 2013). Hal ini bertujuan untuk pemulihan atau pembentukan terumbu karang alami (Sadili et al., 2015).

Sosialisasi pemulihan ekosistem terumbu karang, perlu dilakukan untuk memperbesar keterlibatan masyarakat dan keberhasilan dalam kegiatan pemulihan ekosistem terumbu karang di Perairan Desa Pengudang Kabupaten Bintan. Tujuan kegiatan ini untuk meningkatkan keterlibatan masyarakat dalam pemulihan kerusakan ekosistem terumbu karang di Perairan Desa Pengudang Kabupaten Bintan

\section{METODE}

\section{Waktu dan Tempat}

Kegiatan sosialisasi pemulihan ekosistem terumbu karang dilaksanakan selama 5 bulan, mulai 08 Juni s/d 07 November 2021 di Perairan Desa Pengudang, Kecamatan Teluk 
Sebong, Kabupaten Bintan, Provinsi perendaman dan pemasangan substrat Kepulauan Riau (Gambar 1). transplantasi, pemilihan dan pengambilan

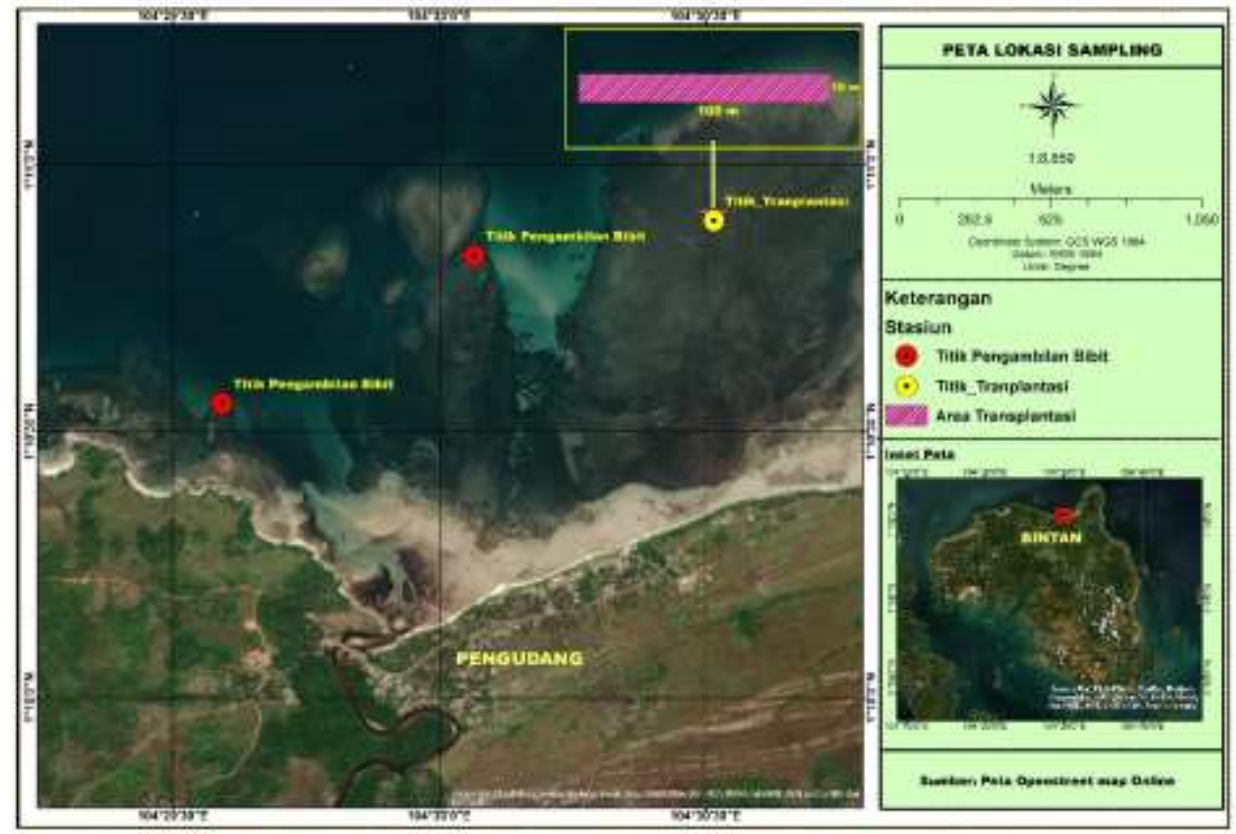

Gambar 1. Peta Lokasi Kegiatan Transplantasi Karang di Perairan Desa Pengudang, Kabupaten Bintan

\section{Prosedur Pelaksanaan dan Analisis Data}

Metode pelaksanaan dalam kegiatan sosialisasi pemulihan ekosistem terumbu karang di Perairan Desa Pengudang, Kabupaten Bintan dimulai dari tahapan persiapan meliputi kegiatan penelitian awal terkait kondisi ekosistem terumbu karang di Perairan Desa Pengudang, tahapan kunjungan ke masyarakat untuk menggali informasi dan permasalahan yang ada di lokasi pelaksanaan pengabdian terkhusus di ekosistem terumbu karang, melakukan survei lokasi pelaksanaan kegiatan pelatihan dan pemilihan lokasi kegiatan transplantasi karang, melakukan pemilihan metode transplantasi karang dengan menyesuaikan hasil wawancara dan observasi di lapangan, melakukan pesiapan alat dan bahan untuk kegiatan pelatihan transplantasi karang.

Tahapan pelaksanaan yaitu melakukan pelatihan dan sosialisasi kegiatan transplantasi yang meliputi penjelasan kegiatan transpantasi, persiapan substrat transplantasi, pelapisan substrat transplantasi dengan menggunakan resin dan pasir, indukan karang, penempelan/peletakkan fragmen karang pada substrat transplantasi, dan penandaan. Tahapan proses kegiatan sosialisasi pemulihan ekosistem terumbu karang di Perairan Desa Pengudang, Kabupaten Bintan dapt dilihat pada Gambar 2.

\section{HASIL DAN PEMBAHASAN}

Kondisi Umum Perairan Desa Pengudang Desa Pengudang terletak di wilayah Kabupaten Bintan, Kecamatan Teluk Sebong, Provinsi Kepulauan Riau. Desa Pengudang memiliki luas wilayah $77,1 \mathrm{~km} 2$ yang secara letak geografis berbatasan dengan Desa Berakit pada sebelah timur, sebelah barat berbatasan dengan Desa Sri Bintan, sebelah selatan Desa Toapaya dan langsung berhadapan dengan laut untuk sebelah utara. Desa Pengudang memiliki sifat perairan terbuka, dengan hamparan lautan luas dan tidak ditutupi oleh pulau-pulau. Perairan seperti ini memiliki potensi yang besar dibidang perikanan, maka masyarakat 
dapat memanfaatkan dengan melakukan aktifitas penangkapan ikan.

Berdasarkan data yang diperoleh dari Kantor Desa Pengudang tahun 2019, kepala keluarga Desa Pengudang yaitu berjumlah $341 \mathrm{KK}$, Jumlah total penduduknya yaitu 1338 jiwa dengan jumlah penduduk laki-laki 714 jiwa dan perempuan 624 jiwa. Mata pencaharian penduduk di Desa Pengudang dominasi oleh nelayan. Kehidupan penduduk sangat bergantung pada hasil tangkapan di laut. Selain melaut penduduk Desa Pengudang juga mencari pemasukan dari petani, buruh, dan sebagainya.

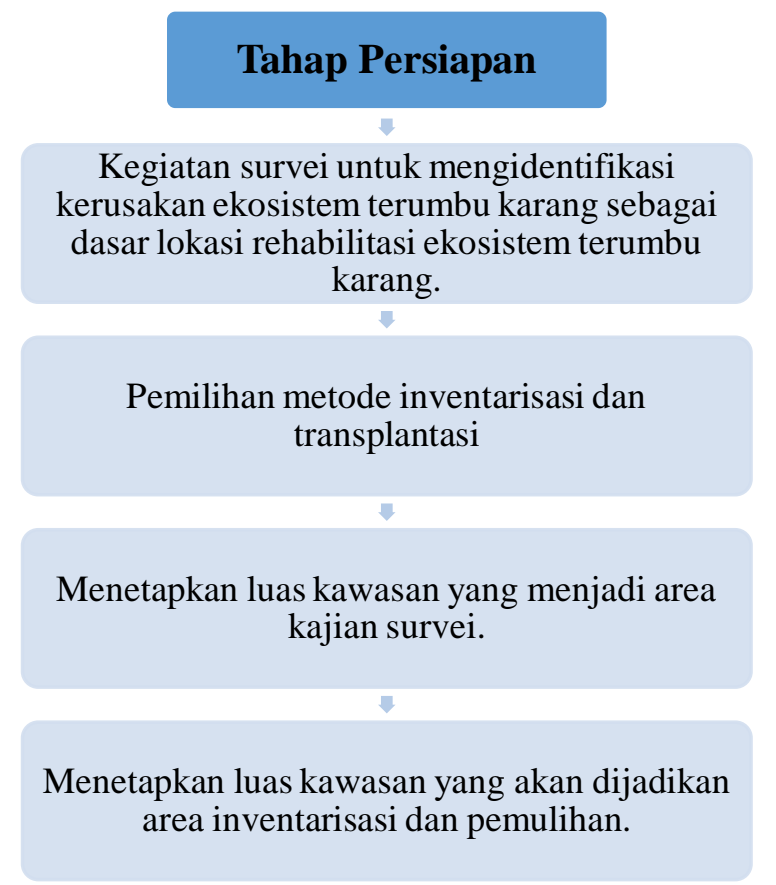

\section{Tahap Persiapan}

Kegiatan survei untuk mengidentifikasi kerusakan ekosistem terumbu karang sebagai karang.

metode inventarisasi da transplantasi

Gambar 2. Tahapan Kegiatan Sosialisasi Transplantasi Karang di Perairan Desa Pengudang, Kabupaten Bintan

\section{Sosialisasi Kegiatan Pemulihan Ekosistem Terumbu Karang}

Kegiatan sosialisasi pemulihan ekosistem terumbu karang dilaksanakan di Ruang Serbaguna Desa Pengudang, Kabupaten Bintan. Kegiatan tersebut dihadiri oleh Perwakilan Dinas Lingkungan Hidup dan Kehutanan (DLHK) Provinsi Kepulauan Riau, Dinas Kelautan dan Perikanan (DKP) Provinsi Kepulauan Riau, Dinas Lingkungan Hidup (DLH) Kabupaten Bintan, Dinas Perikanan (DP) Kabupaten Bintan, Dekan,
Wakil Dekan 1 dan Dosen Fakultas Ilmu Kelautan dan Perikanan UMRAH (FIKP UMRAH), Yayasan Ecology, Kepala Desa Pengudang, Tokoh Masyarakat Desa Pengudang, Kelompok Masyarakat Wisata (Pokdarwis) Pengudang Bintan Mangrove, Kelompok Nelayan Desa Pengudang, Masyarakat Desa Pengudang, Ocean Blue Diving Club UMRAH, dan Ikatan Alumni Fakultas Ilmu Keluatan dan Perikanan UMRAH. Rangkaian kegiatan sosialisasi pemulihan ekosistem terumbu karang berjalan dengan lancar dengan mengikuti Protokol Kesehatan, dimulai dari kegiatan

Koordinasi pelaksanaan program dengan pemerintah daerah, taman nasional, komunitas, perangkat daerah, dan kelompok masyarakat.

Pembuatan model pemulihan kerusakan ekosistem terumbu karang (artificial reef).

Sosialisasi dan bimbingan teknis program pemulihan terumbu karang kepada kelompok masyarakat peduli lingkungan di lokasi kegiatan.

Pelaksanaan transplantasi terumbu karang dengan melibatkan masyarakat sekitar. sosialisasi dan dilanjutkan dengan kegiatan penempelan pasir pada substrat dan simulasi penempelan karang transplantasi. Rangkaian kegiatan sosialisasi pemulihan ekosistem terumbu karang dapat dilihat pada Gambar 3.

Kegiatan pemulihan ekosistem terumbu karang di Desa Pengudang, Kabupaten Bintan mendapat apresiasi positif dari Masyarakat Desa Pengudang, Kepala Desa Pengudang, Pemerintah Kabupaten Bintan dan Pemerintah Provinsi Kepulauan Riau. Dalam sambutannya Kepala Desa Pengudang 
Bapak Kamali Labosa, mengucapkan terimakasih kepada KLHK dan FIKP UMRAH, dan berharap kegiatan ini dapat menjadikan salah satu objek wisata perairan yang ada di Desa Pengudang, serta dari kegiatan pemulihan ekosistem terumbu karang ini diharapkan dapat menjaga kondisi terumbu karang dalam kondisi baik dan meningatkan hasil tangkapan nelayan di Desa Pengudang. Ketua Pokdarwis Pengudang Bintan Mangrove Bapak Iwan Winarto juga mengapresiasi dan berharap kegiatan tranplantasi ini dapat menambah objek wisata perairan yang ada di Desa Pengudang, serta berharap kegiatan ini dapat meningkatan perekonomian masyarakat Desa Pengudang. Beliau juga bersedia menjadi perwakilan masyarakat yang bertanggungjawab pada keberlangsungan keberadaan transplantasi karang di Desa Pengudang. Dokumentasi kegiatan diskusi dan masukan dapat dilihat pada Gambar 4.

Dari perwakilan Pemerintah setempat yaitu Perwakilan Dinas Lingkungan Hidup

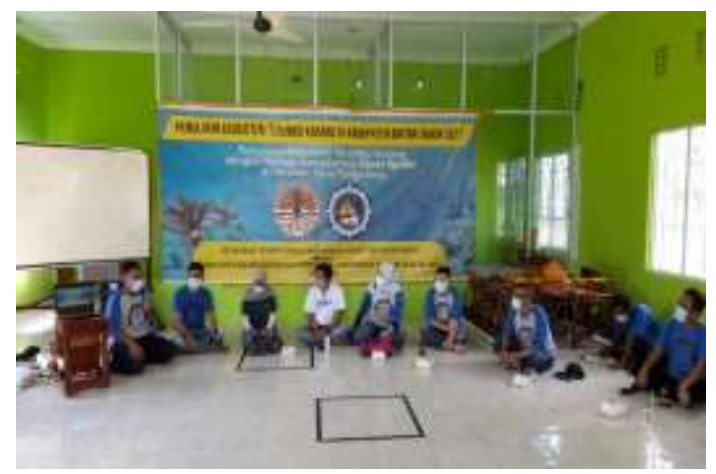

Kegiatan Sosialisasi

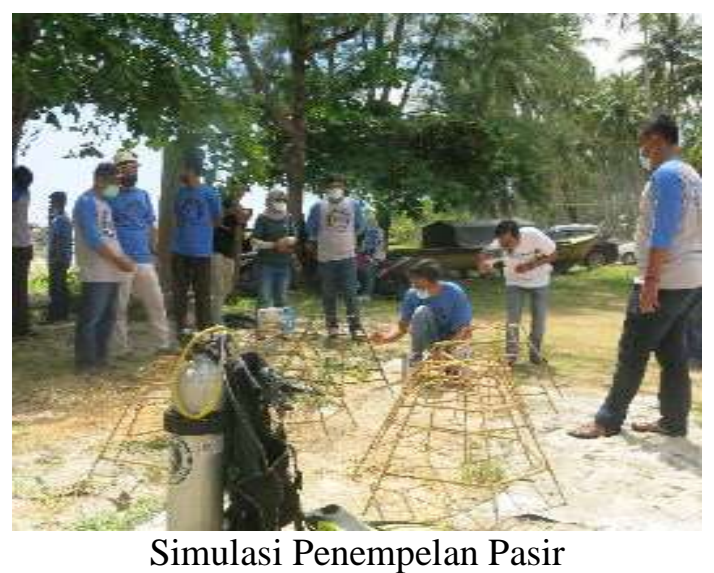

dan Kehutanan (DLHK) Provinsi Kepulauan Riau, dan Dinas Lingkungan Hidup (DLH) Kabupaten Bintan, serta LSM Bidang Lingkungan Yayasan Ecology memberikan apresiasi dan bersedia untuk berkolaborasi dalam menjaga keberadaan lokasi pemulihan ekosistem terumbu karang di Desa Pengudang, Kabupaten Bintan melalui kegiatan yang dilaksanakan oleh instansi masing-masing. Apresiasi dan masukan dari perwakilan Pemerintah dan LSM dapat dilihat pada Gambar 5.

\section{KESIMPULAN}

Telah dilakukan kegiatan sosialisasi pemulihan ekosistem terumbu karang di Perairan Desa Pengudang, Kabupaten Bintan dengan melibatkan masyarakat Desa Pengudang, Pokdarwis Pengudang Bintan Mangrove, Yayasan Ecology, DLHK Prov. Kepulauan Riau, DLH Bintan, DKP Prov. Kepulauan Riau dan Dinas Perikanan Kabupaten Bintan. Kegiatan ini mendapatkan

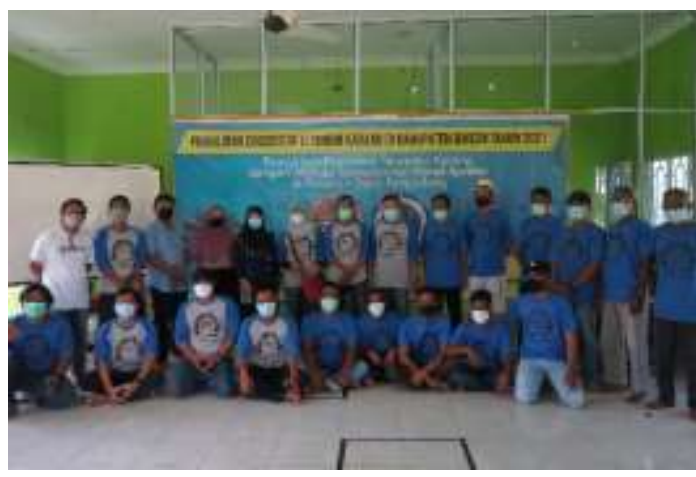

Foto Bersama Peserta Sosialisasi

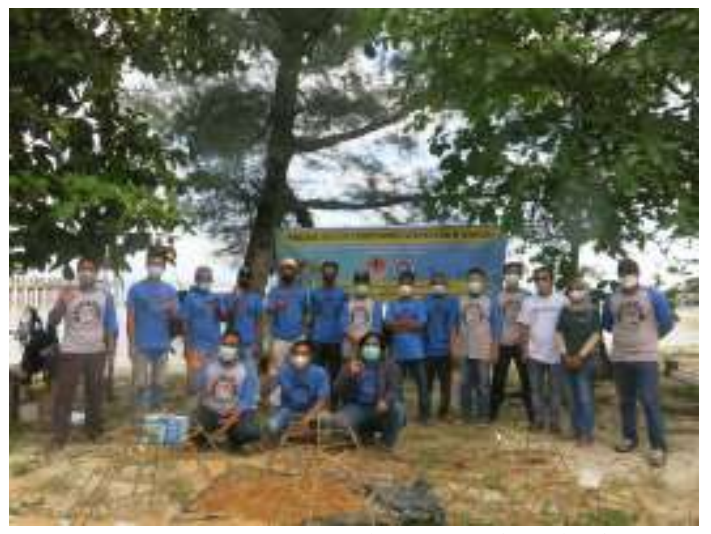

Foto Bersama pada Saat Simulasi

Gambar 3. Sosialisasi Kegiatan Pemulihan Ekosistem Terumbu Karang 
apresiasi dari masyarakat Desa Pengudang, Kabupaten Bintan. Kegiatan lanjutan dari sosialisasi ini yaitu kegiatan pelaksanaan transplantasi karang.

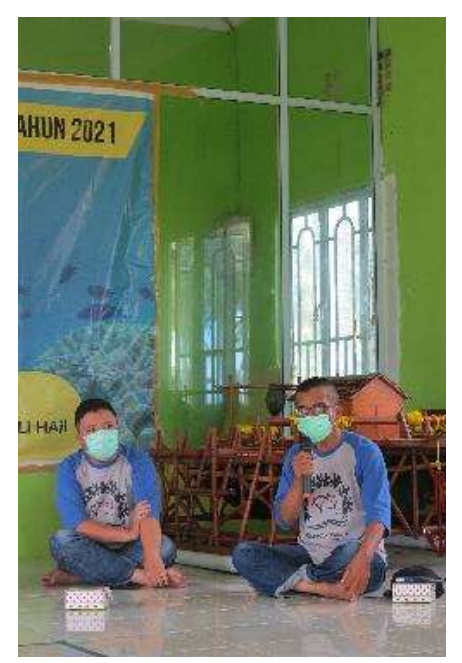

Kepala Desa Pengudang

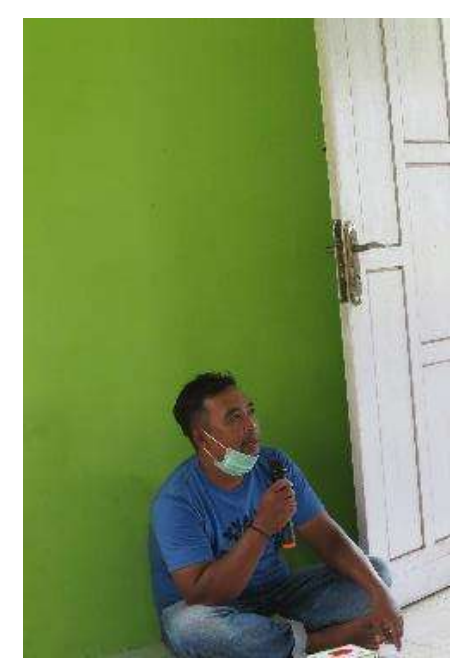

Pokdarwis Pengudang Bintan Mangrove
Bukhari, Putra RD, Kurniawan D. 2021. Optimasi Penggunaan Waktu Pembersihan untuk Suksesi Transplantsi Karang Acropora millepora di Perairan

Gambar 4. Sesi Diskusi dan Masukan dari Peserta Sosialisasi

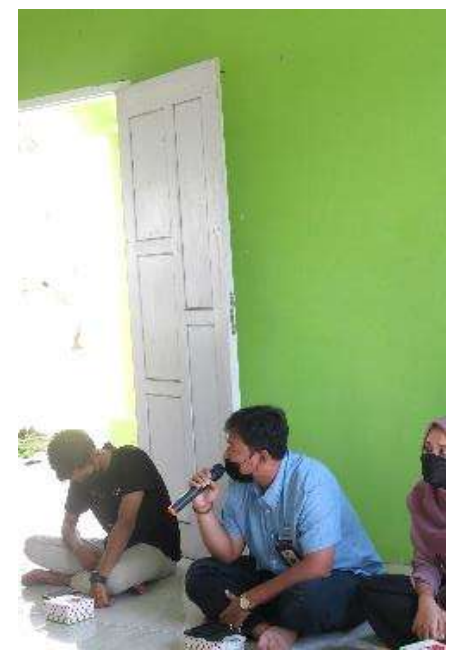

DLHK Prov. Kepri

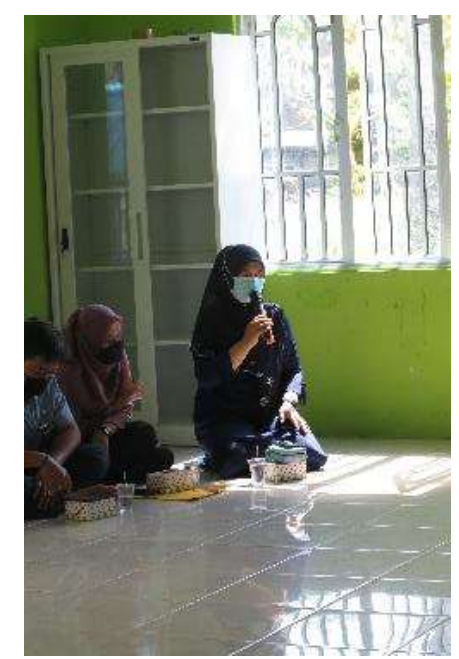

DLH Kabupaten Bintan

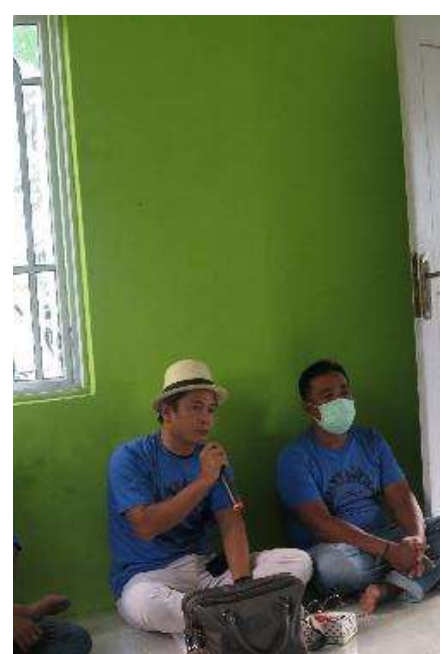

Tokoh Masyarakat Desa Pengudang

Gambar 5. Apresiasi dan Masukan dari Pemerintah serta NGO

\section{DAFTAR PUSTAKA}

Adrian D, Kurniawan D, Putra RD. 2020. Hubungan Persentase Tutupan Karang Hidup dengan Kelimpahan Ikan Indikator Chaetodontidae di Perairan Pengudang, Kabupaten Bintan. Jurnal Akuatiklestari. 3(2): 21-29.
Malang Rapat, Bintan. Jurnal Kelautan Nasional. 16(2): 145-156.

Edwards A, Gomez E. 2008. Konsep dan Panduan Restorasi Terumbu. Yayasan Terumbu Karang Indonesia (TERANGI). Jakarta.

Hadi TA, Giyanto, Prayudha B, Hafizst M, Budiyanto A, \& Suharsono. 2018. Status Terumbu Karang Indonesia 2018. Pusat 
Penelitian Oseanografi - Lembaga Ilmu Pengetahuan Indonesia. Jakarta. 34 hal.

Kurniawan D, Febriyanto T, Hasnarika. 2019. Kondisi Ekosistem Terumbu Karang di Perairan Teluk Sebong, Kabupaten Bintan. Jurnal Pengelolaan Perairan. 2(2): 13-26.

Kurniawan D, Putra RD, Susiana S, Jumsurizal J, Febrianto T, Putri DS, Hasnarika H, \& Ramlan M. 2021. Transplantasi Karang Sebagai Upaya Konservasi Terumbu Karang di Kampung Baru, Lagoi, Bintan. Journal of Maritime Empowerment. 3(2): 26-32.

Lubis SB, Suraji, Mudatstsir, Sari RP, Miasto Y, Prabowo, Monintja M, Tery N, Annisa S, Sofiullah A, Nelly E, Subhan B. 2016. Pedoman Rehabilitasi Bambu Laut (Isis hippuris) Dengan Metode Transplantasi. Direktorat Konservasi dan Keanekaragaman Hayati Laut Ditjen Pengelolaan Ruang Laut Kementerian Kelautan dan Perikanan.

Rahmawati S, Hernawan UE. 2019. Laporan: Pemantauan Kesehatan Terumbu Karang dan Ekosistem Terkait di
Kabupaten Bintan Tahun 2019. COREMAP-CTI, Pusat Penelitian Oseanografi LIPI. Jakarta. 110 hal.

Sadili D, Sarmintohadi, Ramli I, Rasdiana H, Sari RP, Miasto Y, Prabowo, Monintja M, Tery N, Annisa S. 2015. Pedoman Rehabilitasi Terumbu Karang (Scleractinia). Dit. KKHL-KKP RI. Jakarta. 88 hal.

Suharsono. 2008. Bercocok Tanam Karang dengan Transplantasi. LIPI Press. Jakarta. 64 hal.

Suharsono, Siringoringo RM, Hadi TA, Giyanto, Tuti Y, Budiyanto A, Sulha S. 2013. Perkembangan Teknik Transplantasi Karang Di Indonesia. Pusat Penelitian Oseanografi LIPI. Jakarta. 57 hal.

Suharsono, Susetiono, Manuputty AEW, Suyarso, Budiyanto A, Picasouw J, Swasti P, Dharmawan IWE, Rahmawati S. 2014. Monitoring Kesehatan Terumbu Karang dan Kesehatan Ekosistem Terkait di Kabupaten Bintan Tahun 2014. Jakarta : COREMAP-CTI, Pusat Penelitian Oseanografi LIPI. Jakarta. 